\title{
INTERACTION EFFECTS BETWEEN FEED PHYSICAL FORM AND FEED RESTRICTION ON PERFORMANCE AND CARCASS CHARACTERISTICS OF BROILERS
}

\author{
H.H.M. Hassanien ${ }^{1}$, A.A.A. Abdel-Wareth ${ }^{1}$ and A. A. Eldeek ${ }^{2}$ \\ 1- Department of Animal and Poultry Production, Faculty of Agriculture, South Valley University, \\ 83523 Qena, Egypt, 2- Faculty of Meteorology Environment and Arid Land Agriculture, King \\ Abdulaziz University, Saudi Arabia
}

\section{SUMMARY}

One hundred and ninety two, one day old Cobb broiler chicks were randomly distributed into eight treatments to evaluate the effect of feed physical form and feed restriction on body weight, body weight gain, feed intake, gain: feed ratio and carcass characteristics of broilers.

Birds were distributed into two diet forms (mash and pellets). Both mash and pellet diet groups were subdivided into 4 treatments each (T1, T2, T3, T4 and T5, T6, T7, T8, respectively).

In the mash or pellets group, feed was offered to birds as following: T1, T5: birds were fed ad libitum, T2 and T6 (feed removed from 12:00 to 18:00 h during a day), T3 and T7 (feed removed from 23:00 to 7:00 h during a day) and T4 and T8 (removed feed from 23:00 to 9:00 h during a day).

Feed restriction for 6 hour as in the present study resulted in a better gain: feed ratio without reducing carcass weights, and a significant benefit of feeding the mash diet over the pelleted diet was noted in terms of body weight gain, feed intake gain: feed ratio.

Based on these results, it can be concluded that restriction of feed for 6 hours of feeding mash diet increased body weight, body gain and significantly reduced gain: feed ratio but had no consistent effect on overall carcass traits.

\section{Keywords: broilers, feed form, feed restriction, carcass, performance}

\section{INTRODUCTION}

Recently, poultry feed industry continues to search for ways to optimize feed utilization, thereby improving production efficiency, with efforts being focused on changes in diets physical form (Kamphues, 2011). The expected benefits from optimal particle size in feed manufacturing processes include greater surface area, improved handling of most feed ingredients, mixing characteristics of feed ingredients, pelleting efficiency and quality (Mosenthin and Sauer, 2011). Jacobs et al. (2010) stated that it may be beneficial to expose chicks to diets containing large corn particle sizes as early as possible to maximize gizzard size and activity at a younger age; this may help to improve nutrients digestibility.

Early-life fast growth rate is usually accompanied by a number of problems, namely increased body fat deposition, higher incidence of metabolic disorders, higher mortality, and higher incidence of skeletal diseases. To tackle with these problems early nutrient restriction programmes are usually utilized (Lipens et al., 2000; Mazzuco et al., 2000; Lee and Leeson, 2001). Limiting feed intake depresses growth during the period of restriction, but reduced growth can be later compensated by re- alimentation (Govaerts et al., 2000).

Feed restriction programs have shown the potential to reduce the incidence of such problems and can be used to modify birds growth patterns by reducing their maintenance requirements, which consequently should improve feed efficiency (Urdaneta and Leeson, 2002). There are only limited studies that had been conducted using feed restriction systems on broilers and results were insignificant either on growth performance and carcass characteristics (Petek, 2000; Ozkan et al., 2003; Demir et al., 2004; Khetani et al., 2008; Onbasilar et al., 2009). Due to the limitation of data conducted to study effects of combinations of feed physical forms and feed restrictions on broilers performance, the aim of the present study was to evaluate the interaction effects of feed physical form and feed restriction on growth performance and carcass yield of broilers.

\section{MATERIALS AND METHODS}

Experimental animals and housing:

This study was carried out in South Valley University, Qena, Egypt to determine feed intake, growth performance and carcass characteristics of broiler chicks fed two physical feed forms (Mash or Pellets) along with different feed restriction programs. One hundred and ninety-two one-day old Cobb broiler chicks were used and were randomly utilized in a $2 \times 4$ factorial arrangement. Broilers were divided into two main groups each in 4 sub groups (2 physical diet forms $\mathrm{x} 4$ feed restrictions programs) with 3 replicates of 8 birds each. The eight dietary treatments were classified as follow: 
Treatment 1 (T1) a basal diet in mash form and the feed was offered to birds ad-libitum

Treatment 2 (T2) a basal diet in mash form and the feed was removed for $6 \mathrm{hrs}$ (from 12:00 to 18:00 h)

Treatment 3 (T3) a basal diet in mash form and the feed was removed for $8 \mathrm{hrs}$ (from 23:00 to 7:00 h)

Treatment 4 (T4) a basal diet in mash form and the feed was removed for $10 \mathrm{hrs}$ (from 23:00 to 9:00 h).

Treatment 5 (T5) a basal diet in pellet form and the feed was offered to birds ad-libitum.

Treatment 6 (T6) a basal diet in pellet form and the feed was removed for $8 \mathrm{hrs}$ (from 12:00 to $18: 00 \mathrm{~h}$ ).

Treatment 7 (T7) a basal diet in pellet form and the feed was removed for $10 \mathrm{hrs}$ (from 23:00 to 7:00 h).
Treatment 8 (T8) a basal diet in pellet form and the feed was removed for $10 \mathrm{hrs}$ (from 23:00 to 9:00 h).

\section{Diets and management:}

The starter and grower diets (Table 1), were formulated to meet the nutrient requirements of broiler chicks according to (NRC 1994). Both starter and grower diets were in mash or in pellets forms. Birds in each replicate were weekly weighed and the feed consumed was recorded, while feed efficiency (g. gain/ g. feed) was calculated during different experimental periods being starter (121 days), grower (21-42 days) and whole periods (1-42 days). Mortality was recorded daily and calculated for the entire experimental period.

Table 1. Composition and calculated analysis of the experimental diets

\begin{tabular}{lcc}
\hline Ingredients, g/ kg & $\begin{array}{c}\text { Starter diet } \\
\text { (0-3 weeks) }\end{array}$ & $\begin{array}{c}\text { Grower diet } \\
\text { (4-6 weeks) }\end{array}$ \\
\hline Yellow corn & 531.7 & 565.2 \\
Soybean meal (44\%, CP) & 320.0 & 300.0 \\
Corn gluten meal (60\%, CP) & 90.0 & 60.0 \\
Vit \& Min. Premix* & 3.0 & 3.0 \\
Sunflower oil & 20.0 & 40.0 \\
Di-calcium phosphate & 20.0 & 18.0 \\
Limestone & 10.0 & 10.0 \\
NaCl & 3.8 & 3.8 \\
DL-Methionine & 0.5 & --- \\
L- Lysine HCl & 1.0 & --- \\
Total & 1000 & 1000 \\
Calculated analysis: & & \\
ME, MJ/ kg & 12.6 & 13.17 \\
Crude Protein, (g./ kg) & 241 & 215 \\
Crude fibre, (g./ kg) & 0.316 & 0.305 \\
Crude fat, (g./ kg) & 0.462 & 0.665 \\
Ca, (g./ kg) & 0.093 & 0.088 \\
P (Available, g./ kg) & 0.052 & 0.048 \\
Lysine, (g./ kg) & 0.127 & 0.104 \\
Methionine, (g./ kg) & 0.062 & 0.041
\end{tabular}

*A list of the active ingredients used in this feed obtained from the manufacturer: $2.5 \mathrm{~kg} /$ ton $6000 \mathrm{mg}$; Vitamin A, $1200 \mathrm{mg}$; Vitamin D, $10000 \mathrm{mg}$; Vitamin E, $1000 \mathrm{mg}$; Vitamin $\mathrm{K}_{3}, 1000 \mathrm{mg}$; Vitamin $\mathrm{B}_{1}, 5000 \mathrm{mg}$; Vitamin $\mathrm{B}_{2}$, $1500 \mathrm{mg}$; Vitamin $\mathrm{B}_{6}, 50 \mathrm{mg}$; Biotin, $10000 \mathrm{mg}$; Pantothenic, $1000 \mathrm{mg}$; folic acid, $30000 \mathrm{mg}$; Nicotinic acid, 60 gm; Mn, 50 gm; Zinc, 30 gm; Fe, 4 gm; Cu, 3 gm; I, 0.1 gm; Selenium, 0.1 gm; Co.

\section{Carcass traits:}

At 6 weeks of age, five birds from each treatment representing the average body weight of such treatment were slaughtered (8 treatments $\times 5$ birds $=40$ birds). After slaughtering and complete bleeding, birds were scalded and feathers were plucked. Carcasses were eviscerated; heads and shanks were separated, then carcasses were chilled in a tap water for about 10 minutes. Eviscerated carcasses were individually weighed and dressing percentage was calculated (weight of carcass + giblet + abdominal fat/ pre-slaughter weight $\times 100$ ). Percentage of liver, gizzard, spleen and abdominal fat were measured related to live weight.

\section{Statistical analysis:}

Data was subjected to analysis of variance using general linear model (GLM) described in SAS User's Guide (SAS, 2005) as in the following model:

$\mathbf{Y}_{\mathrm{ik}}=\mathbf{U}+\mathbf{D}_{\mathrm{i}}+\mathbf{F}_{\mathrm{j}}+\mathbf{D}_{\mathrm{i}} \mathbf{F}_{\mathrm{j}}+\mathbf{E}_{\mathrm{ijK}}$

Where:-

$\mathbf{Y}_{\mathrm{ik}}=$ an observed value of the concerned trait.

$\mathbf{U}=$ an observed mean for the concerned trait.

$\mathbf{D}=$ the fixed effect due to diet physical form

$\mathbf{F}_{\mathrm{j}}=$ the fixed effect due to fasting system 
$\mathbf{D}_{\mathrm{i}} \mathbf{F}_{\mathrm{j}}=$ the fixed effect due to diet form and fasting period.

$\mathbf{E}_{\mathrm{ijk}}=$ experimental Random error.

Differences among all means of individual treatments were tested with Duncan multiple range test (Duncan, 1955), $\mathrm{P}$ values less than 0.001 were expressed as ' $<0.001$ ' rather than the actual value.

\section{RESULTS AND DISCUSSION}

\section{Feed intake and growth performance:}

The effects of mash or pellets diet form and fasting time on broilers performance is shown in (Table 2) which revealed that the higher body weight (BW) and body weight gain (BWG) were observed in birds fed on mash diets in comparison to those fed pellet diets. The highest feed intake and growth performance were observed in birds restricted for 6 hours. Data in (Table 3) show the interaction between the feed physical form and restriction the heaviest BWG (2237 $\mathrm{g}$ and $2218 \mathrm{~g}$ ) were observed in birds fed $\mathrm{T} 1$ and $\mathrm{T} 2$, respectively during whole experimental period. Moreover, the biggest reduction in BWG $(1717 \mathrm{~g})$ was noted for T8 (pellet form + fasting for 10 hours) as compared by all other dietary treatments.

These results are in agreement with those of Sandilandsa et al. (2006) who found that birds' weight in all restricted treatments increased faster than that of control birds. On the contrary, Scheideler and Baughman (1993) and Deaton (1995) stated that restricting feed supply was found to have no significant effect on broiler performance during growing period. However, Benyi and Habi (1998) reported that chicks fed ad libitum grew faster and were found to be heavier than those on restricted feeding regimes. Also, in the study of Sandilandsa et al. (2006) with broiler chickens $\mathrm{BW}$ of the control treatment in starter period was improved than that of the restricted feeding treatments.

Data in (Tables $2 \& 3$ ) showed that, fasting times significantly reduced $(P<0.001)$ feed intake in all treatments fasted for 6 or 8 hours as compared by control treatment in mash or pellets feed form during the whole experimental period. The present result was in agreement with Lee and Leeson (2001) who reported that birds subjected to transient feed restriction, generally ate less feed than did fullfed (control birds). Feed intake was influenced by particle size, with the intake of fine ground diets being greater than those of coarse ground diets (Amerah et al., 2008). Data in Tables (2 $\&$ 3) indicated that, the feed mashform significantly improved $(\mathrm{P}<0.05)$ broilers gain/ feed ratio during the 1-21 days of age period. The best feed efficiency was observed in birds that continuously fasted 6 as compared by control treatment and all restricted groups (Table 2). However, birds fed pelleted feed and restricted for 6 hours (T6) exhibited the best feed efficiency (Table 3). The improvements in feed efficiency may be related to moderate grinding of feed ingredients that beneficially affect composition of the intestinal microbiota and production of microbial metabolites in the intestine (Mosenthin and Sauer, 2011). Therefore, especially for small feed particle size, higher costs of mechanical processing as well as possible reduction in gut health must be offset by improved nutrient and energy digestibility as well as feed conversion ratio. Amerah et al., (2008) reported that pelleting evened out the differences in particle size distribution in pelleted diets, which resulted in a lack of a wheat particle size effect on broiler performance.

\section{Carcass measurements:}

Concerning the carcass characteristics (Tables 4 \& 5), results indicated that there were significant differences due to diet form on live BW, carcass and gizzard weights. Using different feed restriction systems did not significantly affect carcass weights or liver relative percentages (Table 4). Interestingly, a linear reduction in abdominal fat percent (1.18\% to $0.47 \%$ ) for mash groups and (1.02 to $0.87 \%$ ) for pellet groups were observed among dietary tested treatments. This observation could be due to feed restriction which have been shown to exert a reducing feed intake and subsequently abdominal fat $\%$ in the carcass. This finding agreed with those reported by Palo et al. (1995) who indicated that restricted feeding did not affect the carcass characteristics and the relative weights of different organs, except the relative weight of liver. Pelleting evened out the differences in particle size distribution of wheat-based diets, with no effects observed on performance and gizzard development (Engberg et al., 2002; Svihus et al., 2004; Amerah et al., 2007). There were no significant $(\mathrm{P}>0.05)$ main effects of particle size and grain type on the relative weight of gut components (Amerah et al., 2008). In contrast, the particle size distribution in wheat-based diets remained after pelleting, with positive effects on carcass and gizzard development (Peron et al., 2005 and Lentle et al., 2006). 
Table 2. Effects of feed physical form and feed restrictions on feed intake, feed efficiency and growth performance of broilers from 1 to 42 days of age

\begin{tabular}{|c|c|c|c|c|c|c|c|c|c|c|c|c|}
\hline \multirow[t]{2}{*}{ Treatment } & \multicolumn{3}{|c|}{ Body weight (g.) } & \multicolumn{3}{|c|}{ Body weight gain (g.) } & \multicolumn{3}{|c|}{ Feed intake (g.) } & \multicolumn{3}{|c|}{ Gain / feed (g./ g.) } \\
\hline & Initial 1d $^{2}$ & $21 \mathrm{~d}$ & $42 \mathrm{~d}$ & $1-21 \mathrm{~d}$ & 21-42d & $1-42 \mathrm{~d}$ & $1-21 \mathrm{~d}$ & $21-42 d$ & $1-42 \mathrm{~d}$ & $1-21 \mathrm{~d}$ & $21-42 d$ & $1-42 \mathrm{~d}$ \\
\hline Mash diet & 44 & $860^{\mathrm{a}}$ & $2161 \mathrm{a}$ & $816 \mathrm{a}$ & $1302 \mathrm{a}$ & $2117 \mathrm{a}$ & 1143 & $2361 \mathrm{a}$ & $3575 \mathrm{a}$ & $0.714 \mathrm{a}$ & 0.552 & 0.592 \\
\hline Pellets diet & 43 & $737^{b}$ & $1926 \mathrm{~b}$ & $692 \mathrm{~b}$ & $1189 \mathrm{~b}$ & $1881 \mathrm{~b}$ & 1097 & $2090 \mathrm{~b}$ & $3258 \mathrm{~b}$ & $0.633 \mathrm{~b}$ & 0.569 & 0.578 \\
\hline SEM $^{1}$ & 0.227 & 18.04 & 35.86 & 18.04 & 20.32 & 35.87 & 17.59 & 42.28 & 51.65 & 0.002 & 0.021 & 0.020 \\
\hline P-value & 0.156 & 0.001 & 0.001 & 0.001 & 0.001 & 0.001 & 0.059 & 0.001 & 0.001 & 0.001 & 0.076 & 0.139 \\
\hline Fasting 0 & 44 & $840 \mathrm{a}$ & $2164 a$ & $795 \mathrm{a}$ & $1324 \mathrm{a}$ & $2119 a$ & $1173 \mathrm{a}$ & $2416 \mathrm{a}$ & $3660 \mathrm{a}$ & $0.679 \mathrm{~b}$ & 0.545 & $0.580 \mathrm{~b}$ \\
\hline Fasting 6 hours & 44 & $860 \mathrm{a}$ & $2158 \mathrm{a}$ & $815 \mathrm{a}$ & 1299 a & $2114 \mathrm{a}$ & $1130 \mathrm{ab}$ & $2203 \mathrm{~b}$ & $3404 \mathrm{~b}$ & $0.722 \mathrm{a}$ & 0.590 & $0.621 \mathrm{a}$ \\
\hline Fasting 8 hours & 44 & $780 \mathrm{~b}$ & $1940 \mathrm{~b}$ & $736 \mathrm{~b}$ & $1160 \mathrm{~b}$ & $1897 \mathrm{~b}$ & $1118 \mathrm{ab}$ & $2130 \mathrm{~b}$ & $3318 \mathrm{~b}$ & $0.657 \mathrm{bc}$ & 0.545 & $0.571 \mathrm{~b}$ \\
\hline Fasting 10 hours & 43 & $712 c$ & $1910 \mathrm{~b}$ & $668 \mathrm{c}$ & $1199 \mathrm{~b}$ & $1867 \mathrm{~b}$ & $1059 \mathrm{~b}$ & $2154 b$ & $3283 \mathrm{~b}$ & $0.638 \mathrm{c}$ & 0.557 & $0.567 \mathrm{~b}$ \\
\hline SEM $^{1}$ & 0.227 & 18.04 & 35.86 & 18.04 & 20.32 & 35.87 & 17.59 & 42.28 & 51.65 & 0.001 & 0.166 & 0.020 \\
\hline P-value & 0.561 & 0.001 & 0.001 & 0.001 & 0.001 & 0.001 & 0.020 & 0.001 & 0.001 & 0.001 & 0.083 & 0.139 \\
\hline
\end{tabular}

Values in each column are means for 3 replicates of each treatment

${ }^{1}$ SEM: Standard error of means

2d: day

$\mathrm{a}, \mathrm{b}, \ldots$ Means with different superscripts in the same column are significantly different $\mathrm{P} \leq 0.05$. 
Table 3. Effects of interaction between feed physical form and feed restriction on feed intake (FI) and growth performance of broilers from 1- 42 days of age

\begin{tabular}{|c|c|c|c|c|c|c|c|c|c|c|}
\hline Treatment $^{2}$ & T1 & T2 & T3 $^{1}$ & T4 & T5 & T6 & T7 & T8 & SEM $^{1}$ & P-value \\
\hline \multicolumn{11}{|l|}{ Body weight (.g) } \\
\hline Initial weight 1 day & 44 & 44 & 44 & 43 & 45 & 45 & 43 & 44 & 0.227 & 0.413 \\
\hline 21 day & $905 \mathrm{a}$ & $893 \mathrm{a}$ & $864 \mathrm{~b}$ & $776 \mathrm{~d}$ & $776 \mathrm{~d}$ & $826 \mathrm{c}$ & $697 \mathrm{e}$ & $648 \mathrm{f}$ & 18.04 & 0.001 \\
\hline 42 days & $2281 \mathrm{a}$ & $2261 \mathrm{a}$ & $2043 \mathrm{~b}$ & $2059 \mathrm{~b}$ & $2047 \mathrm{~b}$ & $2055 \mathrm{~b}$ & $1838 \mathrm{c}$ & $1762 \mathrm{c}$ & 34.86 & 0.001 \\
\hline \multicolumn{11}{|l|}{ Body gain (g.) } \\
\hline 1-21 days & $861 \mathrm{a}$ & $849 \mathrm{a}$ & $820 \mathrm{~b}$ & $733 d$ & $731 \mathrm{~d}$ & $781 \mathrm{c}$ & $654 \mathrm{e}$ & $603 \mathrm{f}$ & 17.04 & 0.001 \\
\hline 21-42 days & $1377 \mathrm{a}$ & $1369 \mathrm{a}$ & $1179 \mathrm{~cd}$ & $1284 \mathrm{~b}$ & $1271 \mathrm{~b}$ & $1229 \mathrm{bc}$ & $1140 \mathrm{~d}$ & $1114 \mathrm{~d}$ & 20.32 & 0.001 \\
\hline 1-42 days & $2237 \mathrm{a}$ & $2218 \mathrm{a}$ & $1999 \mathrm{~b}$ & $2016 b$ & $2002 \mathrm{~b}$ & $2010 \mathrm{~b}$ & $1795 \mathrm{c}$ & $1717 \mathrm{c}$ & 34.87 & 0.001 \\
\hline \multicolumn{11}{|l|}{ Feed intake (g.) } \\
\hline 1-21 days & 1209 a & $1183 \mathrm{a}$ & $1189 \mathrm{a}$ & $991 \mathrm{c}$ & $1137 \mathrm{ab}$ & $1077 \mathrm{bc}$ & 1048 bc & $1127 \mathrm{bc}$ & 16.56 & 0.009 \\
\hline 21-42 days & $2610 \mathrm{a}$ & $2351 \mathrm{~b}$ & $2181 \mathrm{cbd}$ & $2304 \mathrm{~b}$ & $2223 \mathrm{bc}$ & $2056 \mathrm{~cd}$ & $2078 \mathrm{~cd}$ & $2004 \mathrm{~d}$ & 41.32 & 0.001 \\
\hline 1-42 days & 3889 a & $3605 \mathrm{~b}$ & $3431 \mathrm{bc}$ & $3365 \mathrm{bc}$ & $3431 \mathrm{bc}$ & $3265 b c$ & $3196 \mathrm{c}$ & $3201 \mathrm{c}$ & 50.56 & 0.001 \\
\hline \multicolumn{11}{|l|}{ Gain/ feed (g./ g.) } \\
\hline 1-21 days & $0.712 \mathrm{a}$ & $0.717 \mathrm{a}$ & $0.689 \mathrm{bc}$ & $0.739 \mathrm{a}$ & $0.646 \mathrm{~cd}$ & $0.727 \mathrm{a}$ & $0.624 \mathrm{~d}$ & $0.536 \mathrm{~d}$ & 0.035 & 0.001 \\
\hline 21-42 days & 0.527 & 0.582 & 0.541 & 0.557 & 0.574 & 0.597 & 0.550 & 0.556 & 0.020 & 0.543 \\
\hline 1-42 days & $0.575 \mathrm{bcd}$ & $0.615 \mathrm{ba}$ & $0.581 \mathrm{abc}$ & $0.599 \mathrm{abc}$ & $0.586 \mathrm{abc}$ & $0.627 \mathrm{a}$ & $0.561 \mathrm{~cd}$ & $0.536 \mathrm{~d}$ & 0.018 & 0.040 \\
\hline
\end{tabular}

a, b, ... Means with different superscripts in the same column are significantly different $(\mathrm{P} \leq 0.05)$.

Values in each row are means for 3 replicates of each treatment

${ }^{1}$ : SEM: Stander error of means

${ }^{2}$ Treatments:

T1: fed mash diet + ad libtum

T2: fed mash diet $+6 \mathrm{~h}$ fasting

T3: fed mash diet $+8 \mathrm{~h}$ fasting

T4: fed mash diet $+10 \mathrm{~h}$ fasting

T5: fed pellets diet + ad libtum

T6: fed pellets diet $+6 \mathrm{~h}$ fasting

T7: fed pellets diet $+8 \mathrm{~h}$ fasting

T8: fed pellets diet $+10 \mathrm{~h}$ fasting 
Table 4. Effects of feed physical form and feed restrictions on some carcass traits of broilers at 42 days of age

\begin{tabular}{|c|c|c|c|c|c|c|c|c|c|}
\hline Treatments & $\begin{array}{l}\text { Live body } \\
\text { weight (g.) }\end{array}$ & $\begin{array}{c}\text { Carcass } \\
\text { weight (g.) }\end{array}$ & $\begin{array}{c}\text { Dressing } \\
\%\end{array}$ & $\begin{array}{c}\text { Abdominal fat } \\
\%\end{array}$ & Liver \% & Gizzard $\%$ & $\begin{array}{c}\text { Spleen } \\
\%\end{array}$ & $\begin{array}{c}\text { Small intestine } \\
\text { weight } \%\end{array}$ & $\begin{array}{l}\text { Small intestine } \\
\text { length }(\mathrm{cm} .)\end{array}$ \\
\hline Mash diet & $2224^{a}$ & $1830^{\mathrm{a}}$ & 82.44 & 0.840 & 3.24 & $3.05 \mathrm{a}$ & 0.361 & 6.81 & 179 \\
\hline Pellets diet & $2011^{b}$ & $1677 \mathrm{~b}$ & 82.37 & 0.856 & 3.36 & $2.62 b$ & 0.334 & 6.52 & 180 \\
\hline${ }^{1} \mathrm{SEM}$ & 65.80 & 60.17 & 0.695 & 0.060 & 0.190 & 0.221 & 0.163 & 0.754 & 1.527 \\
\hline P-value & 0.012 & 0.026 & 0.372 & 0.856 & 0.615 & 0.040 & 0.544 & 0.105 & 0.695 \\
\hline Fasting 0 & 2140 & 1844 & $86.20 \mathrm{a}$ & $1.11 \mathrm{a}$ & 3.17 & 2.51 & 0.300 & 6.29 & 185 \\
\hline Fasting 6 hours & 2194 & 1791 & $81.79 \mathrm{bc}$ & $0.975 \mathrm{a}$ & 3.44 & 2.85 & 0.335 & 7.17 & 178 \\
\hline hours 8 Fasting & 2082 & 1739 & $83.74 \mathrm{ab}$ & $0.636 \mathrm{~b}$ & 3.59 & 3.00 & 0.407 & 6.70 & 178 \\
\hline Fasting 10 hours & 2082 & 1641 & $79.88 \mathrm{c}$ & $0.676 \mathrm{~b}$ & 3.00 & 2.98 & 0.347 & 6.49 & 177 \\
\hline${ }^{1} \mathrm{SEM}$ & 81.88 & 67.01 & 2.354 & 0.068 & 0.203 & 0.211 & 0.666 & 0.906 & 1.452 \\
\hline $\mathrm{P}$-value & 0.623 & 0.181 & 0.004 & 0.002 & 0.270 & 0.346 & 0.324 & 0.468 & 0.616 \\
\hline
\end{tabular}

$\mathrm{a}, \mathrm{b}, \ldots$ Means with different superscripts in the same column are significantly different $(\mathrm{P} \leq 0.05)$.

Values in each column are means for 5 replicates of each treatment

1: SEM: Stander error of means

Table 5. Effects of interaction of feed physical form and feed restriction on some carcass traits of broilers at 42 days of age

\begin{tabular}{|c|c|c|c|c|c|c|c|c|c|c|}
\hline Treatment $^{2}$ & T1 & T2 & T3 & T4 & T5 & T6 & T7 & T8 & SEM $^{1}$ & P-value \\
\hline Live body weight (g) & 2279 & 2341 & 2143 & 2135 & 2002 & 2047 & 2021 & 1976 & 41.47 & 0.246 \\
\hline Carcass weight (g) & 1944 & 1879 & 1755 & 1743 & 1744 & 1703 & 1724 & 1540 & 34.75 & 0.149 \\
\hline Dressing\% & $85.33^{\mathrm{ab}}$ & $80.46^{\mathrm{bc}}$ & $82.03 \mathrm{abc}$ & $81.67 \mathrm{abc}$ & $87.07 \mathrm{a}$ & $83.13 \mathrm{abc}$ & $85.47 \mathrm{ab}$ & $78.09 \mathrm{c}$ & 0.695 & 0.012 \\
\hline Abdominal fat $\%$ & $1.18 \mathrm{a}$ & $1.07 \mathrm{a}$ & $0.63 \mathrm{bc}$ & $0.47 \mathrm{c}$ & $1.02 \mathrm{ab}$ & $0.88 \mathrm{ab}$ & $0.64 \mathrm{bc}$ & $0.87 \mathrm{ab}$ & 0.055 & 0.004 \\
\hline Liver \% & 3.08 & 3.39 & 3.44 & 3.06 & 3.25 & 3.49 & 3.75 & 2.94 & 0.114 & 0.682 \\
\hline Gizzard \% & 2.59 & 2.21 & 2.75 & 2.89 & 2.43 & 3.47 & 3.24 & 3.06 & 0.327 & 0.084 \\
\hline Spleen \% & 0.259 & 0.323 & 0.462 & 0.289 & 0.340 & 0.348 & 0.352 & 0.406 & 0.345 & 0.622 \\
\hline Small \% & 5.85 & 7.25 & 7.31 & 6.82 & 6.73 & 7.09 & 6.08 & 6.15 & 0.456 & 0.372 \\
\hline Small intestine length $(\mathrm{cm})$ & 181 & 182 & 176 & 175 & 188 & 174 & 180 & 179 & 2.119 & 0.810 \\
\hline
\end{tabular}

a,b, ... Means with different superscripts in the same column are significantly different $(\mathrm{P} \leq 0.05)$.

Values in each row are means for 5 replicates of each treatment

1. SEM: Stander error of means

: Treatments:

T1: fed mash diet + ad libtum, $\quad$ T2: fed mash diet $+6 \mathrm{~h}$ fasting, $\quad$ T3: fed mash diet $+8 \mathrm{~h}$ fasting,

T6: fed pellets diet $+6 \mathrm{~h}$ fasting, $\quad$ T7: fed pellets diet $+8 \mathrm{~h}$ fasting, $\quad$ T8: fed pellets diet $+10 \mathrm{~h}$ fasting 


\section{CONCLUSION}

In conclusion, the results of this study suggest that interaction between feed physical form and feed restriction systems significantly improved live body weights, weight gains, and feed efficiency at starter, grower and whole experimental periods. Feed restriction significantly reduced feed consumption and abdominal fat without any side effects on carcass traits and digestive organs. However, more detailed studies are still needed to determine the optimal particle size and the mode of action of these feed physical forms to achieve the optimal growth performance, nutrient utilization and gut health in broiler production.

\section{REFERENCES}

Amerah, A. M., V. RAvindran, R. G. Lentle and D.G. Thomas, 2007. Influence of feed particle size and feed form on the performance, energy utilization, digestive tract development and digesta parameters of broiler starters. Poultry Science, 86:2615-2623.

Amerah, A. M., V. Ravindran, R. G. Lentle, and D.G. Thomas, 2008. Influence of Feed Particle Size on the Performance, Energy Utilization, Digestive Tract Development, and Digesta Parameters of Broiler Starters Fed Wheat- and Corn-Based Diets. Poultry Science, 87:2320-2328

Benyi, K. and H. Habi, 1998. Effect of feed restriction during finishing period on the performance of broiler chickens. British Poultry Science, 39: 423-425.

Deaton, J. W., 1995. The effect of early feed restriction on broiler performance. Poultry Science, 74: 1280-1286.

Demir, E., S. Sarica, A. Sekeroglu, M.A. Ozcan, and Y. seker, 2004. Effects of early and late feed restriction or feed withdrawal on growth performance, and blood constituents of broiler chickens. Acta Agriculture Scandinavica, 54: 152-158.

Duncan, D.B., 1955. Multiple range and multiple F-test. Biometrics, 11: 1-42.

Engberg, R. M., M. S. Hedemann and B. B. Jensen, 2002. The influence of grinding and pelleting of feed on the microbial composition and activity in the digestive tract of broiler chickens. British Poultry Science, 43:569-579.

Govaerts, T., G. Room, J. Buyse, M. Lippens, G. Degroote and E. Decuypere, 2000. Early and temporary quantitative food restriction of broiler chickens. 2. Effect on allometric growth and growth hormone secretion. British Poultry Science, 41:355-362.

Jacobs, C.M., P.L. Utterback and C. Parsons, 2010. Effects of corn particle size on growth performance and nutrient utilization in young chicks. Poultry Science 89: 539544.

Kamphues, J., 2011. Effects of feed physical form on the health of the gastrointestinal tract (GIT) in pigs and poultry. Proceeding Social Nutrition Physiology, 20: 165-167.

Khetani, T. L., Nkukwana, T. T., Chimonyo, M. and V. Muchenje, 2008. Effect of quantitative feed restriction on broiler performance. Tropical Animal Health Production, 41: 379-384.

Lee K. H. and S. Leeson, 2001. Performance of broilers fed limited quantities of feed or nutrients during seven to fourteen days of age. Poultry Science, 80: 446-454.

Lentle, R. G., V. Ravindran, G. Ravindran, and D. V. Thomas, 2006. Influence of feed particle size on the efficiency of broiler chickens fed wheat based diets. Japan Poultry Science, 43:135-142.

Lipens M., Room G., Degroote G. and E. Decuypere, 2000. Early and temporary quantitative food restriction of broiler chickens. 1. Effects on performance characteristics, mortality and meat quality. British Poultry Science, 41:343-354.

Mazzuco H., Guidoni A. L. and F. R. Jaenisch, 2000. Effect of qualitative feed restriction on compensatory growth in the broiler chicken. Pesquisa Agropecuária Brasileira, 35: 543-549.

Mosenthin, R., and N. Sauer, 2011. Nutritional impact of feed particle size in diets for pigs. Proceeding Social Nutrition Physiology 20: 150-156.

National Research Council, 1994. Nutrients requirements of poultry. $9^{\text {th }}$ Ed. Washington, National Academy Press.

Onbasilar, E. E., Yalcin, S., Torlak, E. and P. Ozdemir, 2009. Effects of early feed restriction on live performance, carcass characteristics, meat and liver composition, some blood parameters, heterophillymphocyteratio, antibody production and tonic immobility duration. Tropical Animal Health Production 41: 1513-1519.

Ozkan, S., Akbas, Y., Altan, O., Altan, A., Ayhan, V. and K. Ozkan, 2003. The effect of short term fasting on performance traits and rectal temperature during the summer season. British Poultry Science, 44: 88-95.

Palo, P. E., Sell, J. L., Piquer, F. J., SotoSalanova, M. F. and L. Vilaseca, 1995. Effect of early nutrient restriction on broiler chickens. 1. Performance and development of the gastrointestinal tract. Poultry Science, 74: 88-101.

Peron, A., D. Bastianelli, F. X. Oury, J. Gomez, and B. Carre, 2005. Effects of food deprivation and particle size of ground 
wheat on digestibility of food components in broilers fed on a pelleted diet. British Poultry Science 46:223-230.

Petek, M., 2000. The effect of feed withdrawal during the day on some production traits and blood parameters of broilers. Turkish Journal of Veterinary and Animal Sciences, 24: 447-452.

Sandilandsa, B., Tolkampa, B. J., Savoryb, C. J. and I. Kyriazakis, 2006. Behaviour and welfare of broiler breeders fed qualitatively restricted diets during rearing: Are there viable alternatives to quantitative restriction. Applied Animal Behaviour Science, 96: 53-67.

SAS INSTITUTE, 2005. User's Guide: Statistics. Version 9.1. SAS Institute, Inc., Cary, NC, USA.
Scheideler, S. E. and G. R. Baughman, 1993. Computerized early feed restriction programs for various strains of broilers. Poultry Science, 72: 236-242.

Svihus, B., K. H. Klovstad, V. Perez, O. Zimonja, S. Sahlstrom, and R. B. Schuller, 2004. Physical and nutritional effects of pelleting of broiler chicken diets made from wheat ground to different coarsenesses by the use of roller mill and hammer mill. Journal Animal Feed Science Technology, 117:281-293.

Urdaneta, M. and S. Leeson, 2002. Quantitative and qualitative feed restriction on growth characteristies of male broiler chickens. Poultry Science, 81: 679-688.

\footnotetext{
تاثير التداخل بين شكل العليقة وتحديد الغذاء علي الأداء الإنتاجي وصفات الأبيحة لاجاج التسمين حسام حسين محمد حسانين1، أحمد أبوبكر عبدالمنعم عبدالوارث1، أحمد الديك2

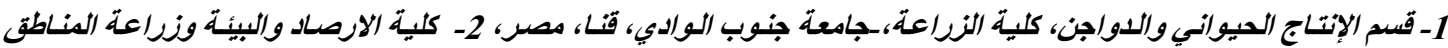

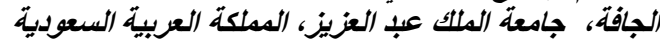

استخدم 192 طائر cobb من دجاج التسمين عمر يوم لتقيم تاثير التداخل بين شكل العليقة وتحديد الغذاء علي وزن الجسم و الغذاء

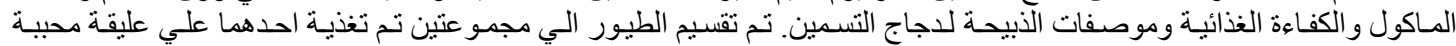

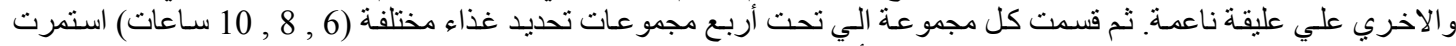

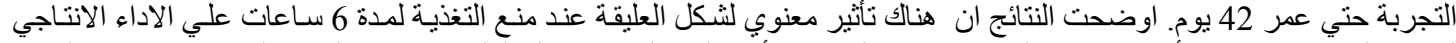

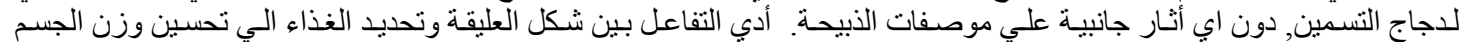

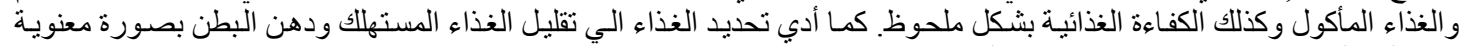
بدون أب تأثثير ضار ولي صلي صفات الذبيحة و أعضاء الجهاز الهضمي.
} 